\title{
ПЕДАГОГ І ДОСЛІДНИК БІОЛОГІЧНОГО ЦИКЛУ
}

\section{Л. Я. Федонюк, Л. Н. Рибіцька, І. В. Гоч, О. Т. Тусик, Л. Б. Ковальова, Л. Б. Муц, \\ М. М. Кланца}

ДВНЗ “Тернопільський державний медичний університет імені І. Я. Горбачевського МОЗ України”

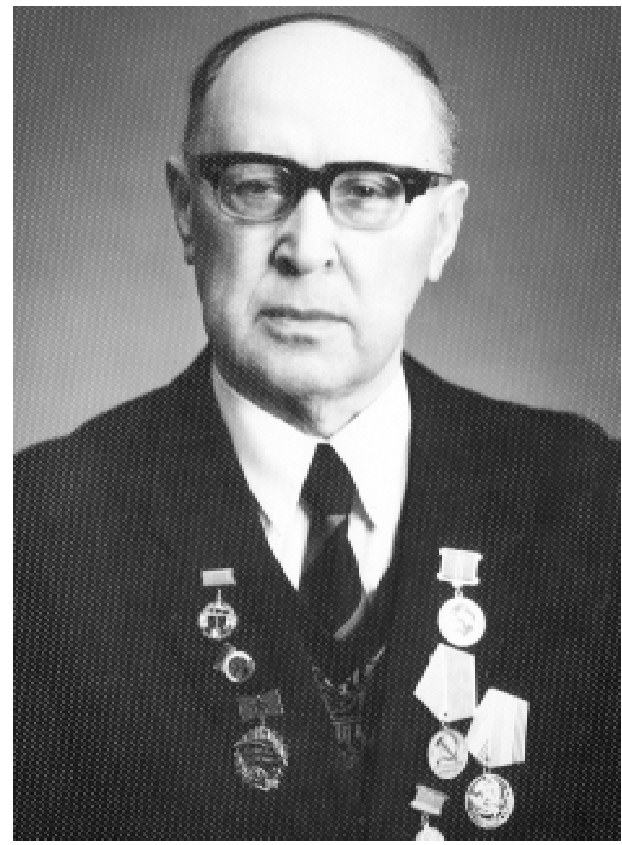

У зв'язку із закликом до людей старшого покоління ділитись з молоддю про жсття минулих часів, хотілось би коротко залишити і свої спогади. Хочеться відтворити історію, яку не зайвим було б знати нинішньому молодому поколінню.

3 автобіографії Івана Івановича Яременка, 22.03.1974 р.)
Іван Іванович Яременко народився 11 червня (28 травня старого стилю) 1903 року в с. Щербаки на Полтавщині у селянській сім'ї.

Босоноге дитинство “минуло непомітно, а трудове життя розпочалося рано”, - згадує Іван Іванович у своїй біографії. "Не забувається початок моїх заробітків, коли семилітнього хлопчика батьки віддали у пастухи на все літо за ... півтора пуда борочна і сорочку”.

До 14 років хлопчик жив із батьками. Взимку ходив до школи, а влітку допомагав по господарству.

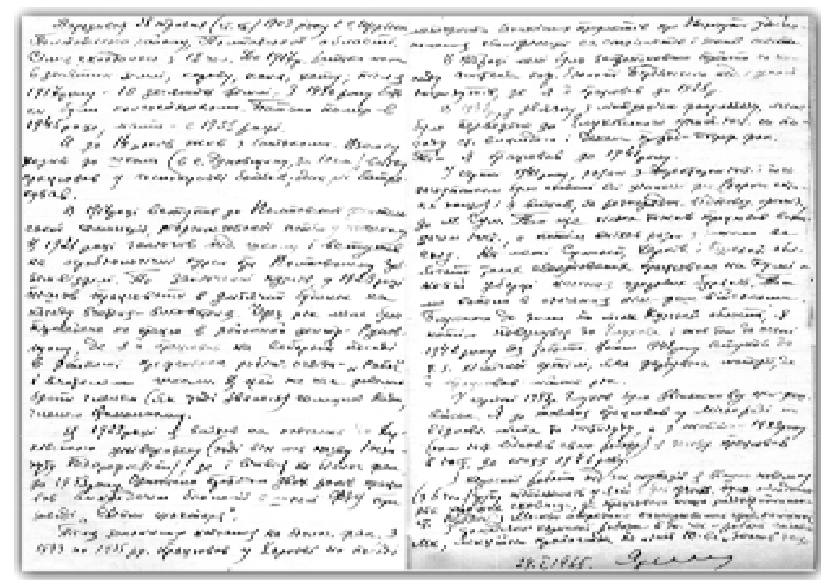

“До початкової иколи з 3-річним строком навчання довелось ходити за 3 кілометри, а потім - до так званого Двокласного міністерського училищза з 5-річним строком навчання - за 10 км, у село Дуновщчину”, - розповідав Іван Іванович. “Вночі доводилось виходити з дому $і$ вночі приходити. Коли траплялась завірюха, такі учні залишались ночувати в школі (спали в класах на підлозі). Книги були дорогі: задачник Малініна і Буреніна коштував 70 коп., а Верещуагіна ще більше. Не можу забути учня Бабича Петра, який жив на квартирі за півтора карбованця в місяць, економлячи на світлі: читав при освітленні місяия”.

"Час закінчення школи видався щзасливим - продовжує спогади I. І. Яременко. - Це був 1917 рік, $i$ Великий Жовтень забезпечив можливість учитись далі, одержуючи державну стипендію. Здійснилась і моя мрія стати вчителем..."

У 1917 році Іван Іванович вступив до учительської семінарії в м. Полтаві, яка пізніше була реорганізована в педагогічну школу, і в 1921 році він став учасником першого випуску радянських учителів для семирічної трудової школи. У цьому ж році I. I. Яременко навчався на агробіологічних курсах при Полтавському губземвідділі та дослідній сільськогосподарській станції, що дало змогу отримати кваліфікацію інструктора для опанування наукових основ сільського господарства. Після закінчення курсів у 1923 році Іван Іванович був призначений учителемвихователем дитячого будинку Мінпросвіти села Терентіївка Полтавської області, що “був розташований поряд з колонією, де праџював А. С. Макаренко. Перша зарплата була 11 крб 40 коп., але прачя була захоплююча, i тому не довелось шукати нічого іншого”.

( Л. Я. Федонюк, Л. Н. Рибіцька, І. В. Гоч та ін. 


\section{З ІСТОРІЇ МЕДИЧНИХ НАВЧАЛЬНИХ ЗАКЛАДІВ}

У 1924 році I. І. Яременко був переведений на роботу вчителя у школі районного центру Руновщина, де працював протягом 5-ти років. Одночасно Іван Іванович очолював райком профспілки "Робос" (робітничої освіти). “То були часи ліквідації неписьменності, а також великого піднесення ідеологічної роботи на селі. Нині трудно повірити, щуо ми, молодь, спали тоді не більше 1-2 ночей на тиждень. Крім лікнепу - робота в Радах, по хлібозаготівлях, кооперування населення”.

31929 року по 1933 рік Іван Іванович навчався на біологічному факультеті Харківського державного університету (Харківський педагогічний інститут професійної освіти). “З житлом для студентів було тяжко, і нас, першокурсників до 500 чол., помістили в церкві з різних вузів. Із похолоданням розбіглись. На біологічному факультеті університету студентів було мало. На 50 місиь екзамени тримало понад 500 чол., прийнято було 44, під кінець I курсу залишилось 25. Викладачі (акад. I. М. Буланкін, А. I. Кіпріянов, О. В. Нагорний, проф. М. М. Фадєєв, Г. Ф. Арнольд, В. В. Станчинський та інші) гарно ставились до студентів. Багато з них жило там же на факультеті. Нам, студентам, була змога працювати, а то й заночувати на кафедрі (все ж краще, ніж на вокзалі). Велика радість була під час міжсеместрової зимової перерви у навчанні одержати ордер на поселення в гуртожитку. Хоч тоді вони були густо заселені й для першокурсників не було ліжок. Згодом ліжка були роздобуті $і$ ми були найщасливіші ”, - так описує I. І. Яременко свій перший рік навчання у вузі.

У 1930 році I. І. Яременко, будучи студентом університету, брав участь у колективізації сільського господарства: “Весною 1930 року мене було відряджено на 1 місяцьь по колективізації в село Мар'їнське Краснокутського району на Харківщчині. Пропуск у навчанні було надолужено самостійною роботою з консультаціями чулих викладачів”.

Наприкінці навчання в університеті Іван Іванович працював викладачем біології в школі ФЗУ при заводі “Світло шахтаря”. Після закінчення університету він отримав спеціальність "Педагог і дослідник біологічного циклу".

31933 по 1935 рік I. І. Яременко працював в Інституті удосконалення кваліфікації сільськогосподарських спеціалістів та заочної освіти на посаді методиста біологічних предметів у м. Харкові.

31935 до 1938 року Іван Іванович працював асистентом кафедри біології та зоології в педінституті м. Бердянська. У 1938 році, у зв’язку з ліквідацією факультету, I. I. Яременка було переведено до вчительського інституту м. Глухова Сумської області, в якому до серпня 1941 року Іван Іванович працював на посаді викладача зоології та деканом природничо-географічного факультету. "У серпні 1941 року... разом із директором інституту та його заступником нами були сховані всі изінності факультету (дорога оптика тощо) $і$ я виїхав за розпорядженням відповідної організачії до міста Суми. Там ще кілька тижнів праџював викладачем інстиmуту, а потім виїхав разом з іншими на схід. На межсі Сумської, Харківської та Курської областей багато таких евакуйованих праџювало на терміновому зборі насіння цукрових буряків. Там ми потрапили в оточення німецько-фашистських військ. Блукаючи до зими по лісах Курської області, я потім повернувся до Глухова і жсв там до осені 1942 року без роботи. Восени 1942 року вступив до так званої хімічної артілі, яка фарбувала матерії, де й праџював майже рік. У серпні 1943 року Глухів було звільнено від німецько-фашистських військ. Я до жовтня працював у Міськраді по відновленню міста", - згадує I. І. Яременко свої роки під час Великої Вітчизняної війни.

Після відновлення Глухівського інституту у жовтні 1943 року Іван Іванович працював у ньому старшим викладачем і заступником директора по навчальній частині інституту до кінця 1946 року.

31947 року по 1957 рік I. І. Яременко займав посаду асистента кафедри біології Станіславського (Івано-

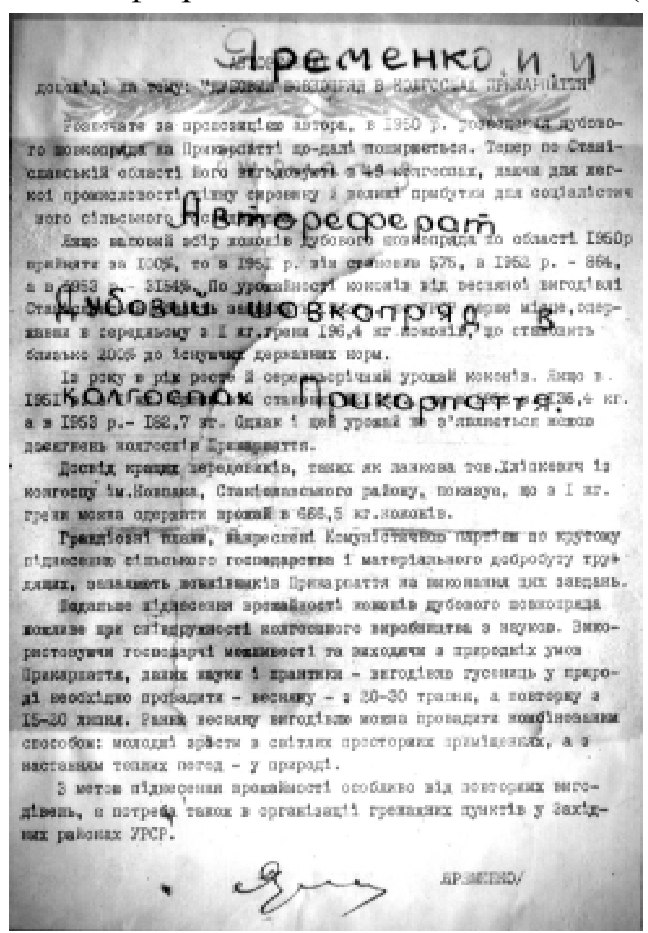


Франківського) медичного інституту та виконував дисертаційну роботу на тему “Дубовий шовкопряд в колгоспах Прикарпаття”. У 1955 році рішенням Ради Інституту зоології АН УРСР І. І. Яременку присвоєно науковий ступінь кандидата біологічних наук.

У червні 1957 року наказом Міністерства охорони здоров' я УРСР І. І. Яременко був назначений на посаду в. о. завідувача кафедри біології Тернопільського медичного інституту в порядку переведення зі Станіславського медінституту.

У листопаді 1958 року рішенням Вищої атестаційної комісії I. I. Яременко затверджений у вченому званні доцента.

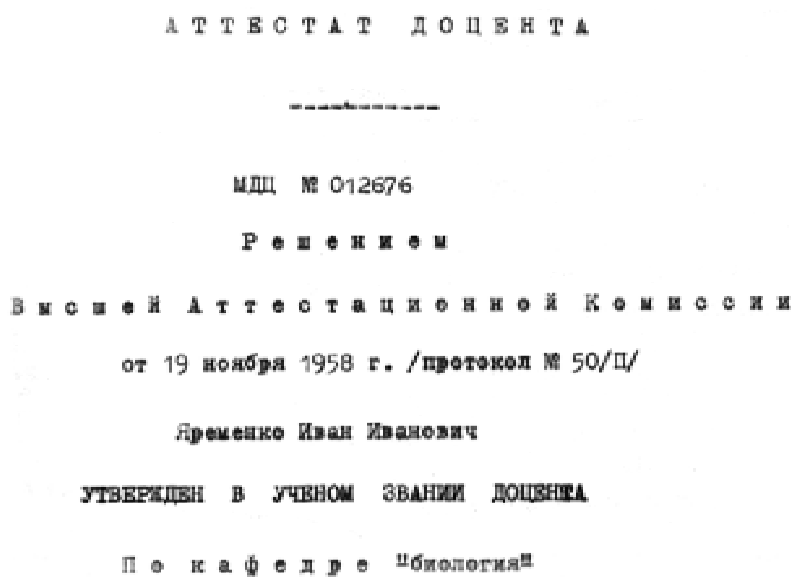

За час роботи у Тернопільському медичному інституті І. І. Яременко проводив активну науково-дослідницьку роботу. Сфера його наукових інтересів: біологічні аспекти фауни та екологічні аспекти флори західних областей України. Він $є$ автором 80 наукових публікацій, в тому числі 4 монографій: "Виготовлення наочних посібників з зоології” (1966), “Біологічний кабінет у школі” (1968), “Отруйні тварини” (1968), “Міф і дійсність”(1971).

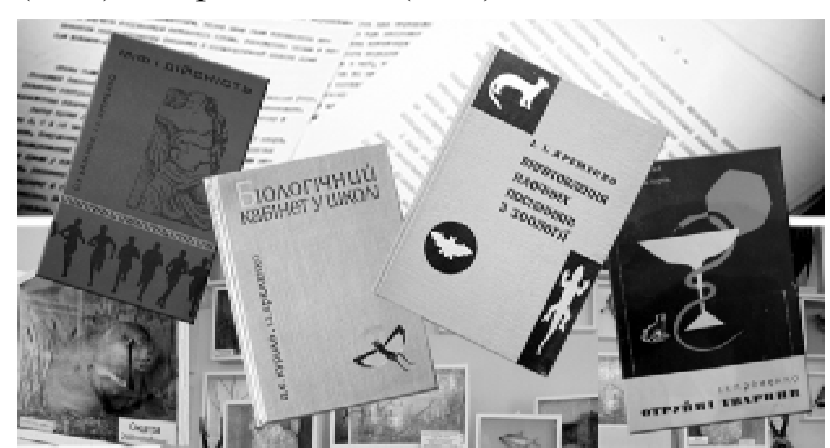

I. I. Яременко має 7 посвідчень на раціоналізаторські пропозиції та ним отримано одне свідоцтво на винахід. При вивченні біології та екології дубового шовкопряда Іван Іванович розробив метод його вирощування на твердих породах дерев (дуб, граб). Його практичні рекомендації використовувалися в колгоспах Івано-Франківської та Закарпатської областей.

Велика кількість робіт Івана Івановича були присвячені питанню про можливість оздоровлення населених пунктів шляхом використання в зелених насадженнях фітонцидовмісних видів рослин. Із цією метою він вивчав фітонцидну активність декоративних і дикорослих рослин із різних родин.

I. I. Яременко започаткував перший науковий напрямок кафедри біології - медичну паразитологію. Протягом багатьох років за консультативної підтримки Івана Івановича проводилися дослідження біологічних особливостей паразитів - гельмінтів і розробка профілактичних мір і засобів боротьби з ними. Під його керівництвом успішно виконані та у 1968 році захищені дві кандидатські дисертації, присвячені вивченню біології збудників трихінельозу (Н. А. Куликова "Распространение и пути передачи трихинелл (Trichinella spiralis, R. Owen, 1835) в Тернопольской области") та ехінококозу (С. П. Марченко "Распространение и биология эхинококка в условиях Тернопольской области").

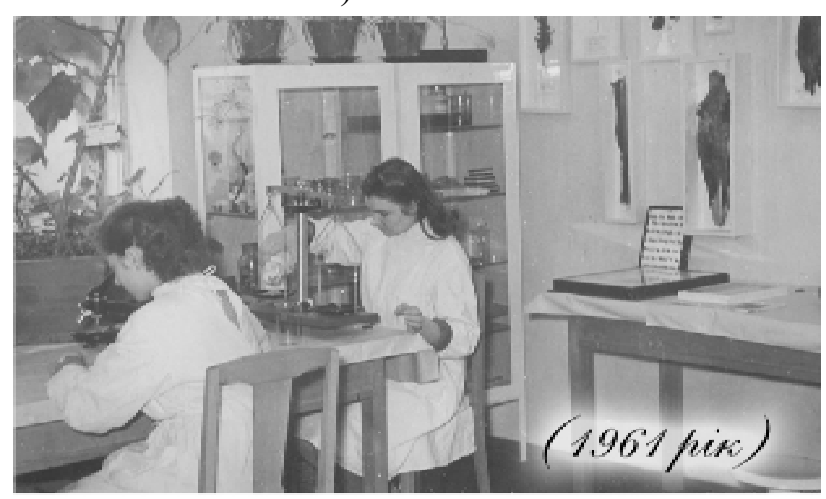

Tnibpabimsuкu кapequ nig rac busonasнs

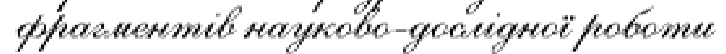

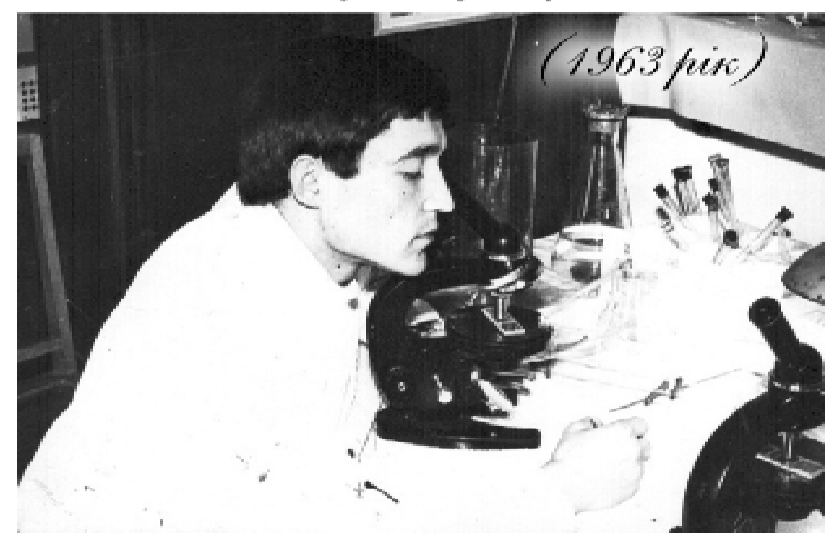

I. I. Яременко брав активну участь у громадському житті Тернопільської області та інституту. Понад 10 років Іван Іванович був депутатом рад, засідателем народного суду, позаштатним лектором райкомів 
партії, головою молодіжних комітетів, членом президії обласних відділень профспілки, уповноваженим райкомів партії по хлібозаготівлях, посівній кампанії.

У період організації та перших років роботи Тернопільського медичного інституту І. І. Яременко очолював молодіжний місцевий комітет, був членом групи народного контролю інституту. У 1958 році Іван Іванович очолив секцію природничо-наукових знань при Тернопільській обласній організації товариства “Знання”. Він був членом пленуму та президії обласної організації цього товариства й головою секції природничо-наукових знань до 1974 року. При організації в 1960 році у Тернопільській області Товариства охорони природи I. I. Яременко був обраний членом президії обласного відділення “Охорони природи” та головою секції пропаганди природоохоронних знань. Протягом багатьох років він був головою Методичної ради Природничого наукового товариства, очолював секцію біологів. Іваном Івановичем надруковано в місцевій та всеукраїнській періодичній пресі до 200 робіт.

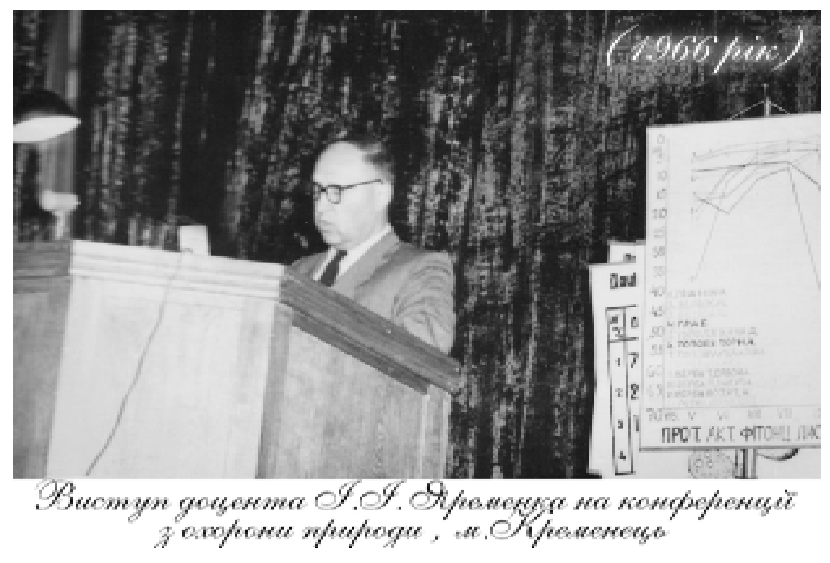

I. I. Яременко надавав вагому методичну допомогу вчителям-біологам області. Щороку він проводив семінари на кафедрі, у школах “Знання про природу” та читав лекції вчителям у різних районах області. Тематика семінарів і лекцій присвячувалася актуальним питанням розвитку біологічної науки та новим

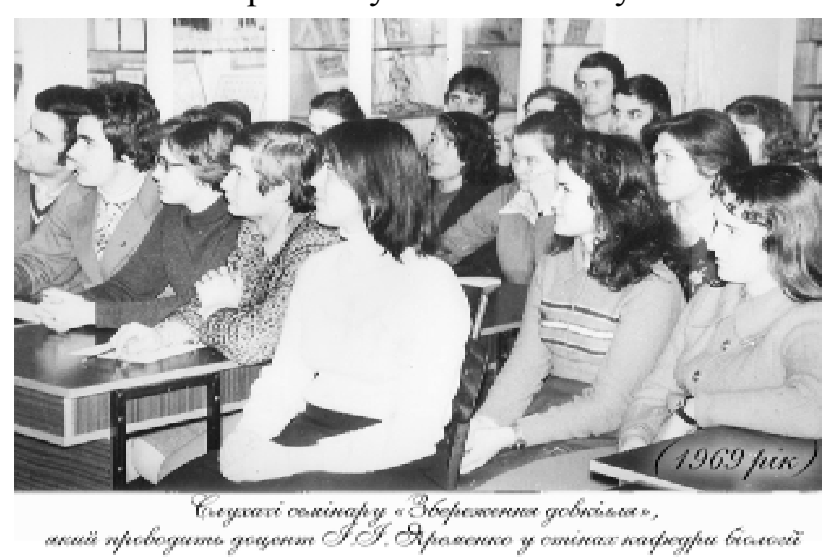

досягненням у біології. Будучи членом бригади по розповсюдженню наукових знань, Іван Іванович виступав на радіо, проводив бесіди серед населення міста і сіл Тернопільської області, брав участь у вечорах запитань і відповідей. Щорічно I. I. Яременко читав для населення Тернопільської області по 3545 лекцій на різні теми сучасної біології та генетики.

Іван Іванович знаний як прекрасний педагог, вихователь молодих викладачів і не одного покоління студентів. Багато сил і енергії I. І. Яременко віддавав вихованню студентів. Часто відвідував гуртожитки, систематично проводив бесіди в студентських групах. Особливо цінними були його поради студентам щодо організації самостійної роботи, дотримання трудової дисципліни, праці над книгою: “Не уявляю собі викладача-вихователя з прогулами чи запізненнями на роботу хоч би й на кілька хвилин. Намагався иі риси прищеплювати й свойм вихованчям. Вважаю, щя це не нудний педантизм, як дехто вважає, а для викладача - конча необхідність".

Іван Іванович майстерно читав лекції та цікаво, на високому науково-методичному рівні проводив практичні заняття, приділяючи велику увагу наочності у викладанні біології, особливо натуральним об’єктам.
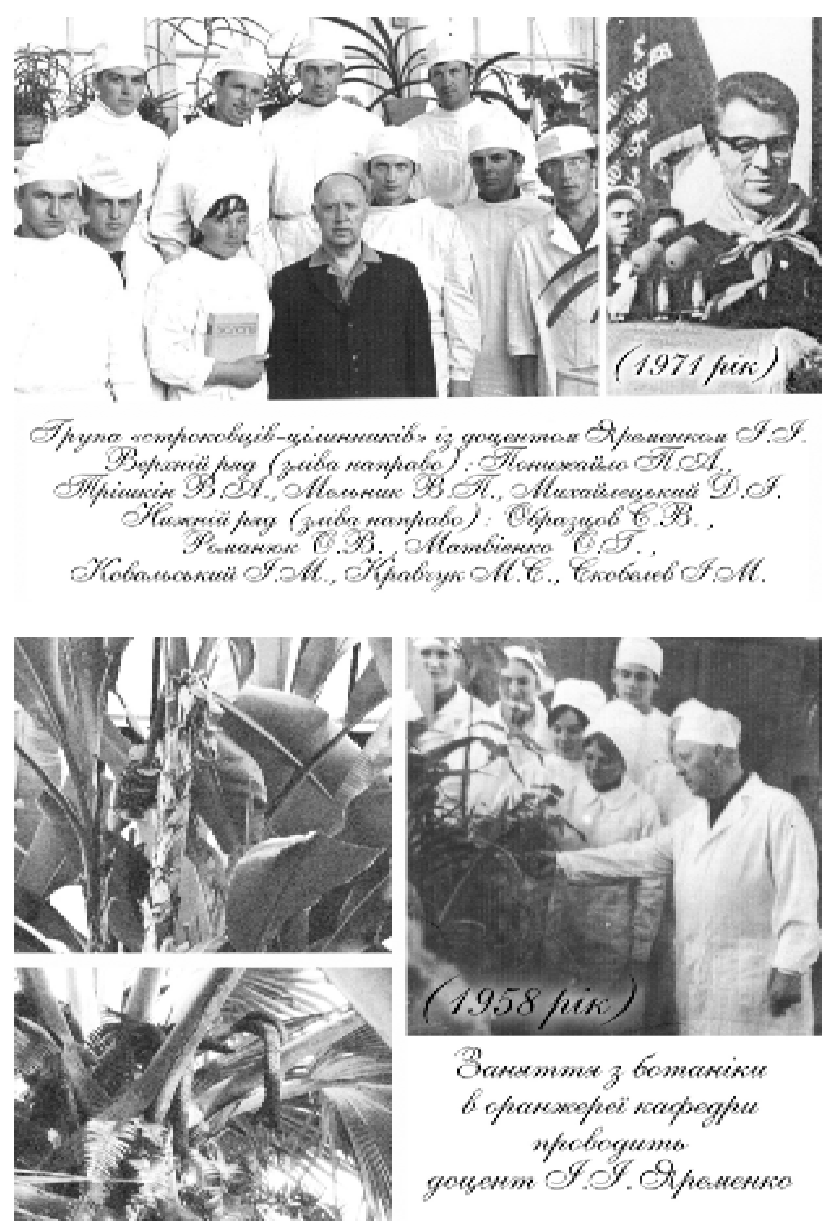
Завдяки його ініціативі на кафедрі біології Тернопільського медичного інституту в 1957 році було створено навчальний біологічний музей. "Виходячи 3 вчення І. П. Павлова про взаємозв'язок першої $i$ другої сигнальної систем, дидактика вищої школи, серед ряду інших засобів, обтрунтувала важливу роль свідомого засвоєння знань, в тому числі студентами вузів. Серед різноманітності наочностей одне з перших місиь повинні зайняти натуральні об'єкти і їх зображення, які створюють найповніше уявлення змісту оточуючої нас живої природи. 3 огляду на це, певне місие в на-

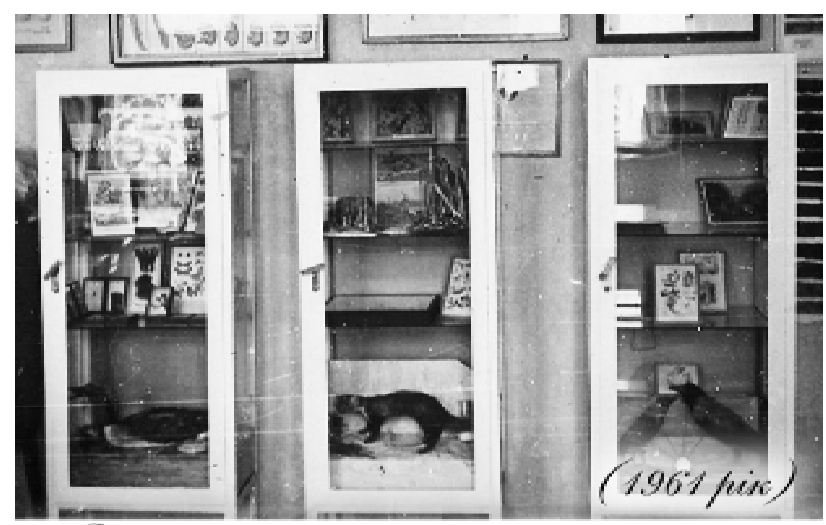

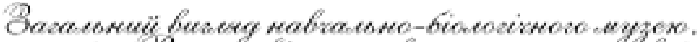

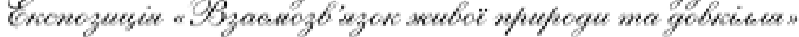

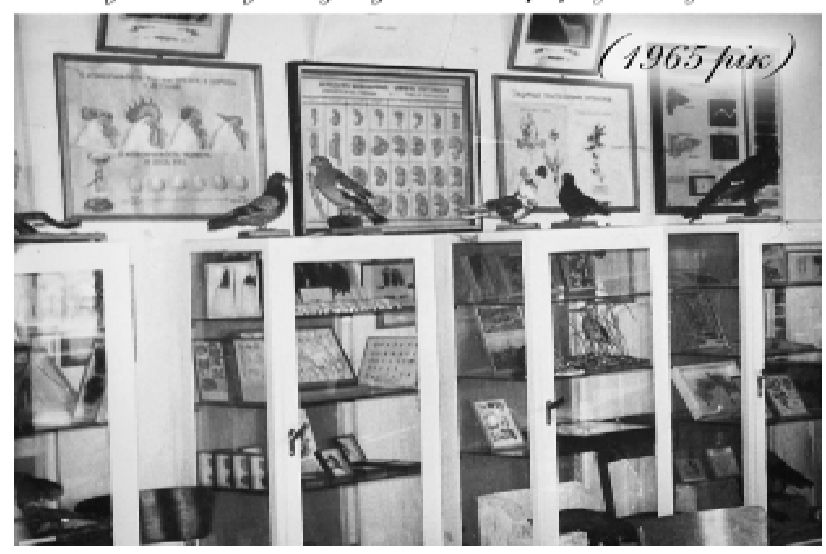

У 1967 році відбулось урочисте відкриття музею, що збіглося з 10-ю річницею заснування Тернопільського медичного інституту. Музей має багатогранне значення: навчальне, наукове та виховне. Навчальне: експонати музею відображають тематичні розділи програми 3 дисципліни, за допомогою яких студенти спостерігають взаємозв'язок рослинного та тваринного світу, організмів між собою та навколишнім середовищем, формують уявлення про будову багатоклітинних організмів, а також вивчають роль людини у зміні природних екосистем. Наукове: експозиції секцій музею цінні тим, що формують систему знань про закони природи, вони є базою для дослідження основ вчально-виховному проиесі повинні зайняти музеї. Це особливо має актуальне значення при вивченні однієї з фундаментальних дисииплін - біології", - зазначав I. I. Яременко у короткому довіднику про навчальний музей, написаному ще у 1974 році. При оформленні тематики біологічного музею $з$ понад 2000 експонатів особливу увагу Іван Іванович надав показу єдності організмів і середовища, походження живого з неживої матерії, великої різноманітності рослинного та тваринного світу, сучасних принципів побудови організмів, процесів розмноження та розвитку, питань спадковості та мінливості.

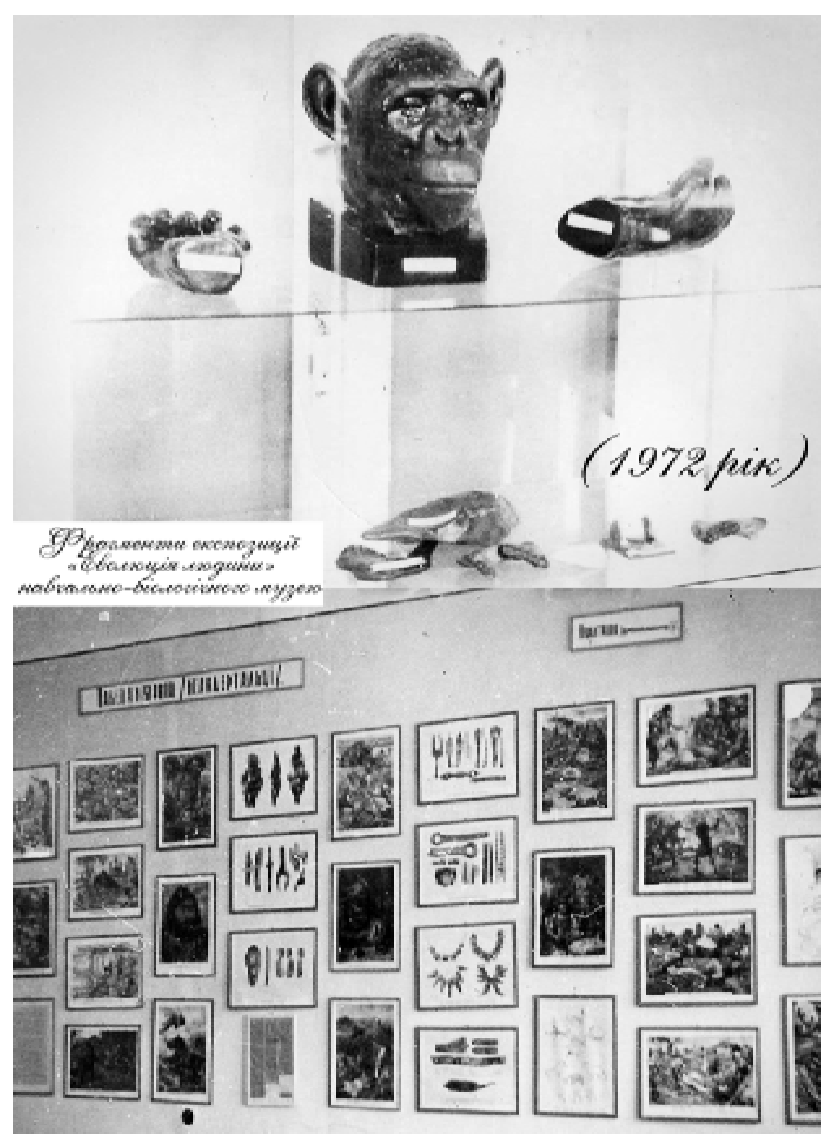

паразитизму та паразитарних інвазій у людини. Виховне: музей формує гуманне, дбайливе та бережливе ставлення до природи рідного краю, вміння естетично ставитись до всього живого. До складу експонатів музею входять опудала тварин рядів хижаки, парнокопитні, гризуни, черепахи, голубоподібні, куроподібні, лускаті, перетинчастокрилі, та інші, а також велика кількість муляжів, схем і препаратів, більшість 3 яких виготовлено особисто І. І. Яременком. Музей завжди був та залишається гордістю вузу, насамперед гордістю за людей, які заклали його фундамент.

У 1970 році доцент I. I. Яременко був нагороджений медаллю “За доблестный труд”. У своій біографії 


\section{З ІСТОРЇ̈ МЕДИЧНИХ НАВЧАЛЬНИХ ЗАКЛАДІВ}

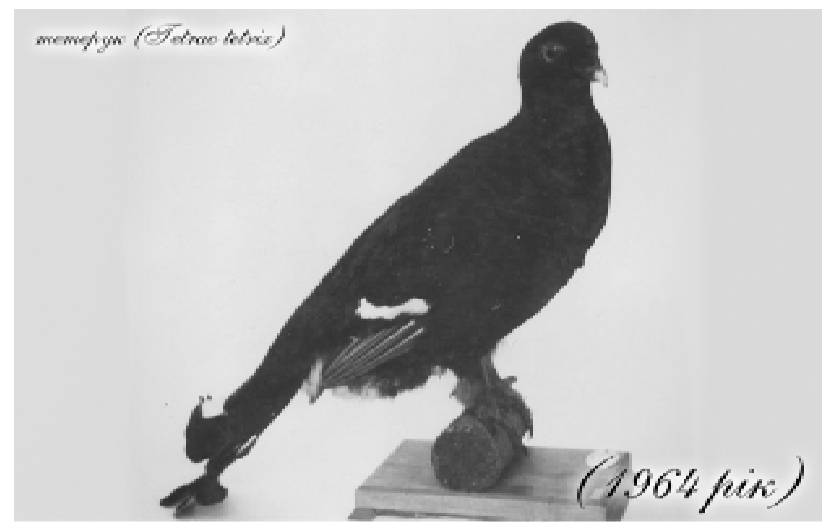

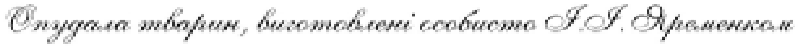

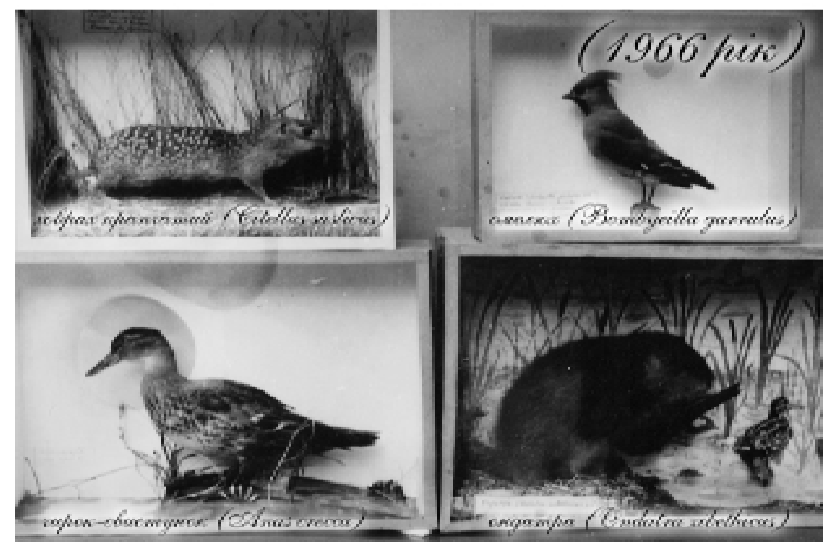

Іван Іванович згадує, що “працюююч в системі Міністерства освіти та Міністерства охорони здоров'я, мав заохочувальні відзнаки, усні подяки та неодноразові потиски руки Міністра”.

Завідував кафедрою I. І. Яременко до липня 1974 року.

Помер Іван Іванович Яременко 27 грудня 1978 року у віці 75 років.

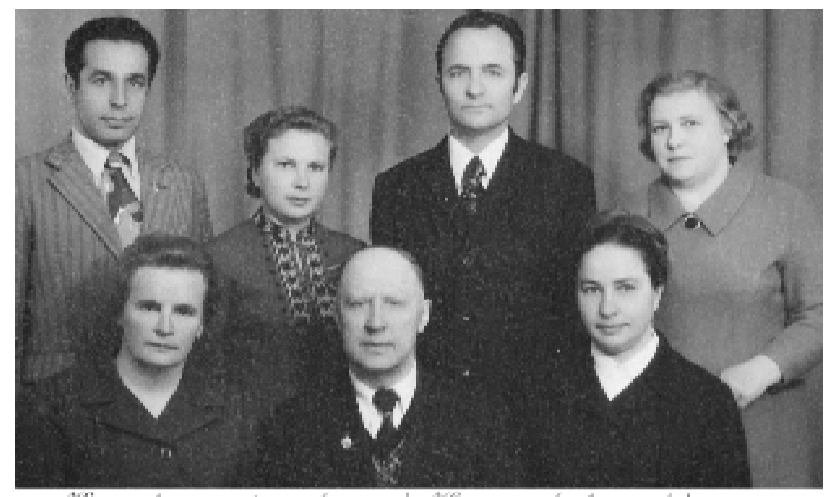

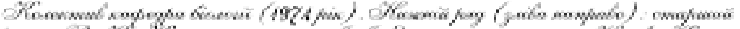

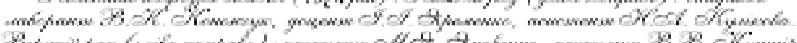

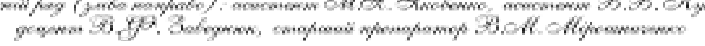

